\title{
Christian fathers as role models of the church's fulfilment of the Missio Dei in a fatherless society
}

\section{Fazel Ebrihiam Freeks ${ }^{1}$}

\begin{abstract}
Families remain the world's oldest, most basic form of relationship. However, in the 21 st century, families are undergoing multiple crises. The fact cannot be ignored that numerous families experience no fatherly presence. Several missiologists emphasise that a church with an understanding and vision of God's mission (missio Dei) must train parents to take up the task of nurturing children in faith. The term missional has true meaning. It is not merely a Christian buzz word or a catch phrase that families can use as an act. "Missional" should be viewed as an activity of God because it is rooted in Scripture and modelled by Christ. God has not given up on the vital role of the family. Therefore, family life requires the proactive impartation of biblical principles. The role of the family is accentuated within the biblical narrative and its importance is consistently brought to the attention of God's followers. Christian parenting entails that parents model and educate their children in conduct that embraces God's compassion for people who do not enjoy a living relationship with him. Christian fatherhood ${ }^{2}$ can guard against father absenteeism since Christian fathers lead sacrificial lives for the sake of their families. The hearts of Christian fathers are filled with a God-given mission aiming to instil a love for Christ in the hearts of their children.
\end{abstract}

Keywords: Christian, fathers, role models, church, Missio Dei, fatherless society, missional, missional fatherhood

\section{Introduction}

All fathers have a God-given role to fulfil in the family. The father is the priest and head of his family and must govern the family according to the principles and regulations of the Bible as found in 1 Corinthians 11:3 ( $c f$. Freeks 2008:28-29). But fatherhood has changed over time, and as a result, most families are struggling with serious problems, consequences and challenges in their respective communities (Linn et al. 2015:12-13). One of the serious problems in fam-

Fazel Ebrihiam Freeks is an associate professor and Coordinator: Community Engagement in the Faculty of Theology at the North-West University, Potchefstroom Campus. He can be contacted at 10589686@nwu.ac.za or fazel.e.freeks@gmail.com

2 This article is part of a thesis: Freeks, FE. 2018. A missional evaluation of the LIFEPLAN® training and equipping programme for youth in rural areas. A case study of its impact in the Christiana district of South Africa. 
ily life is fatherhood itself. God calls humans to function as parents ( $c f$. Freeks 2011a:83). The father is accountable before God to lead his family with sacrificial love. Children understand the concept of God better if they understand their earthly or physical father. The father has to demonstrate a godly character and he must be a follower of Christ and must reveal certain characteristics, such as humbleness, softness of heart and patience towards his children according to 2 Tm 2 ( $c f$. also Freeks 2008:28-29).

\section{What is Christian parenting and being missional?}

In this context, Christian parenting and being missional means that the father and mother cooperate on behalf of their children to help realise God's greater plan for the world. The practical situation is that parenting can be difficult. However, parents should strive to be the guardians God wants them to be for their children. Furthermore, parents should take this responsibility seriously by seeking guidance from the Lord through his wisdom, grace and knowledge. They should recognise parenting as their primary mission in life (Anon. 2016a; Wax 2016).

In the church's fulfilment of the Missio Dei, Christian parents should do mission within the family situation by acting biblically sound. Christian parents should keep in mind that God did not intend for them to do mission alone, but as a family together. Thus, Christian parents must understand that their mission begins with Jesus Christ and does not primarily lie with them as members of the family. Being Christian parents, they should understand that Jesus Christ was the first and most complete missionary in history (Bevins 2016).

Furthermore, being missional and Christ-like is to be active in mission, which means conveying the Gospel of Jesus Christ overall, whether at home, in church, or in the community. The researcher postulates that families can be missional in multiple ways, for example in knowing their neighbours; involving themselves in the schools their children attend; participating in community activities; helping those in need, either physically or spiritually; and praying, especially for those who have not yet received the Gospel (Magruder 2014).

Wolter (2014) shares an interesting narrative of missional parenting. He points out that parents currently are more concerned to protect their children from the world, instead of preparing them to make a difference in society. The researcher concurs with Wolter that parents should prepare their children to contribute to society. This preparation should be done as mission and in line with the will and purpose of God for their lives. Parents should avoid over-protecting their children or being fearful of what might happen when their children reach out to others. Fearful parents should be made aware that this emotion is detrimental, since they cannot fulfil their parenting role effectively. 
Furthermore, it is essential for parents to understand that missional parenting differs from other forms of parenting. Missional parenting is Gospelcentred. The analogy can be applied to both fathers and mothers as courageous warriors releasing their children into battle (into a world of problems, challenges and choices).

\section{What is missional fatherhood?}

In the context of missional fatherhood, the father takes on the leading role as missional father within the family. Furthermore, missional fatherhood implies that fathers accept and follow a specific role. This means to live sacrificial lives for the sake of their families and catering for the needs of others. The hearts and lives of these fathers are committed to a God-given mission where they model and inculcate the love of Christ into the hearts of their children. These fathers should also sacrifice their time to help the community (Waresak 2016b).

Missional fathers can be called "Micah's fathers", as described in Micah 6:8:

He has told you, 0 man, what is good; and what does the Lord require of you but to do justice, and to love kindness, and to walk humbly with your God?

Furthermore, missional fathers must engage with their children about aspects that matter most in life, such as striving for a life that glorifies God. In other words, these fathers should become preoccupied with the business of God the Father (Waresak 2016b; cf. Rm 12:1; 1 Cor 10:31).

Parents should shape their children's worldview bite-sized. This means the father should expose children to the needs of others in the world, with the motivation to reach a lost and dying world for Christ. It is furthermore important that the father and family should meet the various needs together, for example, experiencing mission jointly as a family. He should also convey his passion for mission to the children by discussing it and allowing them to observe his excitement for mission. He must also ensure immediate obedience and response from his children in the home for assignments and suggestions. His children are allowed to ask questions or disagree. However, it is vital that they first listen to his ideas and suggestions for doing mission.

Now that we have a broad comprehension of what Christian parenting and being missional and missional fatherhood entails, it is crucial to view the dilemma of father absenteeism and fatherlessness to understand why the father should be a guard against father absenteeism and fatherlessness. Thus, it is crucial to discuss this current problem as it has emerged globally. 


\section{The current fatherhood problem in the world}

\subsection{Research done in the world about the fatherhood problem}

Father-absenteeism is a phenomenon that does not only occur in local communities, but is a world-wide tendency (Bartlett 2013:1-3; Dobbs 2013:2; Family life 1998:1; Freeks 2013:3; Popenoe 1996; Staples 1999; Williams 2014). Research was undertaken in 21 countries of the world, and in every country, four specific issues were identified as the most severe problems in society: drugs, violence, unemployment and fatherlessness (Carstens 2014:9-11; cf. Freeks 2004:1-6; Freeks 2011a:1-4; Freeks 2013:8-18; Freeks et al. 2015a:22-24; Freeks \& Lotter 2009:520-524; Richter et al. 2012).

Fatherlessness is a serious concern. Carstens (2014) identifies it in his research as the fourth-ranked problem of the world. Evidently families world-wide suffer immensely due to this fatherhood problem.

Research continually confirms that fatherhood is paramount. Notwithstanding the changing world, fathers still play a unique role in the development of their children's behaviour, life choices, relationships and self-esteem (Waresak 2016a; Waresak 2016b; Vaughan, 2010).

Certain studies argue that fathers who are involved in family life and connected with family members are non-violent towards their children, do not abuse drugs and are more content, healthier and more productive at work (Levtov et al. 2015:514). However, this finding does not apply to all families. Even if the father is not prone to substance abuse or acts non-violently, there are cases of abuse (Brelsford 2011; Knafo 2003; Williams 2008).

\subsection{Is fatherlessness a root cause of dysfunctional families?}

Research has shown that dysfunctional family life is a major problem, with fatherlessness at the centre (Carstens 2014:9-11; Freeks 2004:1-6; Freeks 2011:1-4; Freeks 2013:8-18; Freeks 2016a:6-7; Freeks et al. 2015:22-24; Freeks \& Lotter 2009:520-524; cf. Richter et al. 2012).

The following statistics reflect some of the disturbing factors in South Africa: $63 \%$ of suicides originate from fatherless homes; $70 \%$ of juveniles in state-operated institutions are products of fatherless homes; $80 \%$ of rapists motivated by displaced anger come from fatherless homes; $40 \%$ of all children in this country do not live with their biological fathers; $85 \%$ of children with behavioural problems come from homes where the father is absent; $90 \%$ of homeless children are from fatherless homes; $71 \%$ of children who do not finish school come from such homes ( $c f$. Carstens 2014; StatsSA 2015b; Goodsell \& Meldrum 2010).

From the statistics above it seems that most major social pathologies can been linked to fatherlessness or absent fathers. Men must understand that they play a 
vital role in the welfare of their family and society. If they do not fulfil this role, the following statistics may keep on rising: men commit $90 \%$ of major crimes; men commit $100 \%$ of rapes; men commit $95 \%$ of burglaries; men commit $91 \%$ of the offenses against the family; men comprise $94 \%$ of drunk drivers ( $c f$. Carstens, 2014:10).

Statistically, it is evident that there is a "fatherhood disease" in the world and a rapid increase in single parenting. This fatherless epidemic is defining a generation of children in South Africa.

A pattern has emerged where social pathologies are linked to fatherlessness. It could be expected that a child who had grown up in a household with an absent father did not have the example of what it means to be a true father themselves (Meintjies \& Hall 2013:86-89). There is a trend where absent and abusive fathers themselves had no role model of paternity. Statistically, families and society at large cannot escape the insufferable truth that there is a fatherhood disease in the world. This fatherless epidemic is defining a lost generation of children (Herald Reporter 2002:18). If the situation regarding fatherhood globally seems acute, it is crucial in the context of the present study to examine closely the current fatherhood problem in South Africa.

\subsection{The current fatherhood problem in South Africa}

\subsubsection{Statistics of children growing up without fathers in South Africa}

Colonisation and urbanisation transformed family arrangements extensively during the 20th century in South Africa, not to mention the roles that parents played, especially the crucial one of the father (Richter et al. 2010:361-362). In 2012, South Africa was rated as one of the countries in the world with the highest figures of father absenteeism (Freeks 2016a:6; Richter et al. 2012:2).

Therefore, it is not surprising that this is identified as one of the main factors that place family life in jeopardy (Bertelsmann 2016). Since the beginning of the 21st century, South African society has neglected the importance of fatherhood (Ratele et al. 2012). The researcher believes that in several cases the family is redefined, and, significantly, the father does not even feature in this definition (Ford et al. 2008).

From a biblical point of view, this problem originated with the fall of humans into sin. This resulted in a cycle of problems caused by fathers who are not fulfilling their role presently (Gn 3:1-24).

South African fathers do not differ that much from fathers elsewhere. However, South Africa has unique circumstances that impact families. For example, during the era of the migrant labour system, families were disrupted because fathers had to leave their immediate family and work in the mines and cities. They only returned 
home over the Christmas period (Frazier, 2015). It is shocking that South Africa has the second highest rate of father absenteeism in Africa after Namibia (Richter et al. 2010:360).

To compound matters, father absenteeism is on the increase in the South African context. This tendency generates problems such as broken families, aggressive behaviour among children, as well as financial and social ills and poverty (Freeks 2016a:2). The problem of father absenteeism escalated from $42 \%$ to $48 \%$ in 2011 in South Africa (Bartlett 2013:1). In the present study, it is important to note that this mentioned absence results in a desperate cry for help and a deep concern since numerous households are run by single mothers (Amoateng et al. 2004; Herald Reporter 2002). This matter is far-reaching and worrying since statistics reveal that $31 \%$ of mothers are raising their babies without a father figure.

Furthermore, 1.1 million births were registered in 2015, of which 64\% indicated that information about the biological father is lacking. Such cases eventually result in single parenting. Single parenting is the leading cause of the fatherhood problem in South Africa. In 2015, approximately 886202 babies were born, and $50 \%$ of the women who gave birth were single mothers with no assistance from the biological fathers (Hawkins 2015).

Another concerning fact related to children growing up without fathers in South Africa is the fact that 5.3 million of these children are younger than five years, and in $93 \%$ of cases, both parents are alive (Mkhize 2013:2). These children comprise approximately $10 \%$ of the population, but many live in adverse conditions due to fatherlessness. Comparing this problem among the different races is disconcerting. Approximately 33\%$38 \%$ of Black children live with their fathers, and $79 \%$ with their mothers, compared to the $87 \%$ of White children who live with their fathers (Mkhize 2013:2).

The increasing number of absent fathers has become not only a dilemma, but cause for serious debate in South Africa. In 2010, the South Africa Institute of Race Relations related statistics indicating that $56 \%$ of divorces were by parents with children, and $48 \%$ of these children were left without fathers. It also resulted in a total of 3.95 million orphans, which is another dilemma on the increase in South Africa (Frazier 2015). The unfortunate reality for most of the children is that 50\% of all fathers in South Africa do not have daily contact with their children (Richter et al. 2010:361). A further negative aspect is that $63 \%$ of reported youth suicides in South Africa originate from fatherless homes (Frazier 2015).

A further disturbing factor is that a third of the country's prisoners are between the ages of 18 and 25 years and they have children outside the prison walls. Research has indicated that if children grow up without fathers, factors such as poor educational outcomes and anti-social behaviour may result in disrupted employment (Frazier 2015). Furthermore, certain enhancing factors are directly or indirectly influenced by 
the presence of the father. These include health, well-being, academic performance, self-confidence and behaviour control in boys and girls (Frazier 2015).

\subsubsection{Reports on father absenteeism, children growing up without fathers and fatherlessness in South Africa}

In South African society, there is a distinct lack of positive father figures (as role models). Analysts refer to this problem of fatherlessness as a "fearless monster" and "corrosion of fatherhood" that destroyed families (Anon. 2008a:15; John 2012:24; Swartz et al. 2013). This corrosion is a major cause of the current societal ills in South Africa, seeing that $30 \%$ of children are born into single-parent homes. In Black communities, this figure is even more disturbing, increasing to 68\% (Feni 2016:2).

According to statistics from 2013, 5.3 million children were fatherless. By 2015 the number was 9 million. These statistics hold an immense fatherhood challenge for the country. The survey also found that paternal orphanhood is consistently higher than maternal orphanhood. Orphanhood has also become critical due to the HIV/Aids pandemic in South Africa as both parents often lose their lives. Furthermore, the survey indicated that 1651 adoptions were registered during the period of 1 April 2014 to 31 March 2015. This holds a critical risk factor for the development of missional fatherhood (Dube 2016:2).

"South Africa is rapidly becoming a fatherless society with men behaving like monsters towards women and children." This was one of the critical statements raised at a forum held in Mthatha in the Eastern Cape, investigating fatherless societies and the decline in fatherhood (Feni, 2016:2; Anon., 2004). Furthermore, it was stated that the influence of fathers in families has declined significantly since the period of democracy in South Africa. At this forum, men were urged to change since they have the capacity and willpower to reset their boundaries, restore their image, and start afresh with renewed values (Feni 2016:2).

The researcher concurs with Feni that men should develop renewed values. However, change will not be possible if they do not experience a total change of heart. Men should first renew their mind with the Word of God according Romans 12:2. Thereafter, they should allow the Holy Spirit to lead them in cultivating a Christian character as fruit of the Spirit as described in Galatians 5:22: faithfulness, self-control, patience, et cetera. These characteristics should be their new starting point. The most profound change in understanding fatherhood will come from knowing God as Father (Smail 1980:10). In addition, Smail elucidates that ignorance about the biblical doctrine of God as Father in certain churches impede the members' missional activities. To this effect, Smail makes the following challenging statement: 
The charismatic experience can most certainly rejuvenate people and churches, but how much evidence is there that it can mature them, by delivering them from their insidious self-concern and making them profitable and outward-moving members of the body of Christ? The answer to that depends on considerable measure on how they relate to the Father (Smail 1980:10).

It is important to understand that fatherless households are a fact of South African society and cannot be ignored any longer. The problem is complex since there are no clear paths or solutions to take on this detrimental societal problem. For example, during the xenophobic attacks in 2008, the perpetrators were described as the "fatherless sons of violence" (Anon. 2008b:15). During these attacks, numerous people, especially men, were brutally murdered, beaten up, stabbed and raped, and more children were left fatherless (Hans 2008:5). The negative impact of these attacks was that millions of children and adolescents were left without parents (Anon. 2008a:15; Anon. 2004).

Even psychologists argue that during this time a lack of adequate parenting caused behavioural problems among the youth. Psychologists mention further that many Black men lack the capacity to be a father to their children because their own fathers were absent and deserted them. This situation caused severe family breakdowns and disrupted community structures, seeing that young boys and men turned to gangs and crime, which destroyed social structures (Anon. 2008b:15).

\section{The importance of Christian fathers and missional fatherhood in families}

\subsection{Becoming a father shaped by God the Father through His Word}

Fathers are not only parents they are the leaders of their own family. Therefore, they have a responsible role to shape the quality, mood, tone and texture of this interactive fundamental unit that is the family (Brooks 2008:7). Before parents can answer God's calling and care for their family optimally, they must first take care of themselves. Parents are responsible to God. They have a divine calling to be examples for their children. Biblical parenting entails covenant education (Bergh 2002:105-110; 119 \& 121-122; Morris 2007:12; Steytler 2007:28-30). Parents should focus on themselves first. However, the researcher believes that fathers should first take care of "God's business" before taking care of their own business (Phlp 4:19).

Testimony in the Scripture is clear on the fact that God places high value on family life. For example, the Bible provides more information and commandments on the aspect of family than any other structure in society. Therefore, it is important that every believing family should understand their task and calling to participate in the Great Commission of God, namely winning over the world for Jesus Christ (Buys 1983:320; Mt 28:19-20). 
God should be an essential Presence within family life, seeing that the family is important in the eyes of God (Freeks 2011a:155). Christian families have a missional task to serve the Lord, as Joshua confirmed to the Israelites: “... but as for me and my household, we will serve the Lord" (Jos 24:15).

It is also vital to understand that parenting is a relation and an activity. When fathers and mothers manage their family, they must focus on building relations (McGraw 2004:8). Importantly, the father must function as role model and a follower of Jesus Christ so that he cultivates in his family a love for God and his Word (Freeks 2004:95-98).

Furthermore, parents stand in a relationship with God. The results of their faith cascade down to the children, who are nurtured by the work of the Holy Spirit. Therefore, it is crucial for parents to understand that their religious life influences their children to seek the presence of God (Freeks 2011a:156).

\subsection{The importance of the house altar or fellowship within the home}

The house altar refers to family devotions, which entail daily sessions where family members hold fellowship within the home. They read and share Bible passages, discuss Christian doctrine, pray together, and sing Christian songs and hymns. This may include celebrating family members' days and commemorating special days: repentance and baptising "birthdays', as well as the Lord's Supper (Freeks 2011a:165; Goheen 2011:221-223).

In this context, the father acts as the priest in the family. His main task is the spiritual gathering of his family and instituting the house altar. Furthermore, it is crucial that the father takes the lead at the house altar. He should teach his family that God has greater plans for them as a unit and individually and that they should prosper in the various areas of their lives (Jr 29:11). The house altar is not only important, but is an effective way for the family to read and study the Word of God together (Bergh 2002:168).

In correlation with the proposed house altars, family members should strive to base their actions, behaviour and attitude on God's Word. They should consider God's guidance in the various areas of their lives and follow the biblical perspective. Adding value to the present study, it is essential to elaborate on the elements of such a house altar. These aspects are discussed below.

\subsubsection{Prayer meetings}

In the prayer meetings, the father must lead his family and make the family's prayer requests known to God as their heavenly Father (Freeks 2004:95-98). Such meetings are crucial building blocks for spiritual growth within the family as a unit. The father's task is to ensure his children apply this spiritual discipline (prayer), which will be a positive sign of their closeness to God as heavenly Father. If family mem- 
bers are unable to identify with God as Father, it may imply an inadequate relationship where they do not pray together with their earthly or physical father (Warren 2005:53). The outstanding aspect of a prayer life is that it connects a person to God and builds that individual's faith to enjoy God as heavenly Father (Mt 5:6; 26:41; Mk 11:24; Lk 11:1; 18:1).

The father should confirm with his family that God will not only listen to their prayers as family members, but also answer them as a family unit (Ps 55:1; Mt 7:7$11 ; 11: 22 ; 1$ Pt 3:7).

\subsubsection{Bible study}

Within the context of the house altar, the father must emphasise the vital point that the Bible is the constitution in the home. The family should not only love the Word of God, but should study it diligently ( $2 \mathrm{Tm} 2: 15)$. The family members should follow the biblical guidelines and cultivate a passion for God's love and His Word. Such an approach makes God the priority in their lives (Hart \& Hart Frejd 2010:8-9).

Furthermore, studying the Bible will make the family understand that they are fragile, fallible and liable to err. Therefore, they need to place their lives and trust in God as their heavenly Father who guides and provides (Freeks 2011a:131; $c f$. also Jn 18:11).

To handle the word of truth correctly, the family has to study the Bible. The members must be guided to apply biblical directives in their daily circumstances.

\subsubsection{Singing songs and hymns}

Christian families should also sing Christian songs and hymns. This is a way for the family to praise and worship God for his provision and his protection over their lives. This exercise is not only imperative for family spirituality, but such an attitude can inspire other families (Freeks 2011a:127).

Significantly, the father can teach the children about the value of Christian music. He can motivate them to sing gospel songs and hymns, seeing that such music has the power to uplift people's spirit. This exercise can also provide a solid foundation for the family's house-altar environment, as discussed previously. To sing spiritual songs together can inspire and motivate a family when the members face life's challenges.

It is important to know that God is present in the praises of his people. The father should make it a priority and explain to his family that God "inhabits the praises of his people" according to Psalm 22:3. Furthermore, singing, or "making music and a joyful noise unto God" is relieving and refreshing for a family's faith, helping them worship the Lord and honour his name (Ps 66:1-2).

Worship in the home is vital, seeing that children learn how to adore and appreciate God by worshipping Him through songs and praises. Often children are excluded from the worship and life of the local congregations. Thus, parents have 
the major responsibility of including children in the worship at home. The father should take a leading role, encouraging the children to participate in the worship in church as well as at home. A suggestion would be for fathers to provide children with notebooks where they can write down aspects of a sermons that touch them. This will encourage children to be attentive in the local church and at the home altar (Goheen 2011:223).

The father should guide the children to understand the importance of worship. This practice is the central calling of the church and at home. Worshipping together gives the family direction and focus in their lives (Goheen 2011:202). Worship entails showing respect and reverence to God (Ps 29:2; Is 66:23; Mt 2:2; 4:10; Ac 24:14; Phlp 3:3; Rv 4:10). It is the researcher's belief that the family should be trained and equipped for this vital but difficult missional task, namely nurturing children to worship God as their heavenly Father through the stories of the Bible and the guiding example of the parents.

\subsubsection{Significant salvation moments}

Days commemorating family members' repentance and celebrating their "baptising birthdays" should be special within a Christian family. It is the father's duty to make these significant salvation moments memorable events in the home. Concomitantly, the father should encourage his children to give their lives to Jesus Christ when they reach the proper age. Jesus requests people to repent, which also applies to the children coming of age if they were not baptised at birth (Mk 1:4; Rm 6:4; $1 \mathrm{Pt}$ 3:21; Mt 3:11; Mk 1:8; Lk 3:16).

The father should teach his family that repentance and baptism are visible signs that they as a family have decided to change their lives, giving up a sinful way of living and turning to God. Afterwards, the father should establish unique "birthdays" to celebrate repentance and baptism. This would be occasions where the family gather together as they do for other birthdays (with a cake, etc.) and celebrate these specific day(s). On such occasions the father leads the members to reflect on the significance of their renewal and the forgiveness of their sin (Ps 25:18; Mt 3:2; 6:12; 9:5; 9:6; Mk 2:7; 11:26; Lk 6:37; 7:47; 13:3; Ac 2:38; Eph 4:32; Col 2:13; 2 Pt 3:9; 1 Jn 1:9).

It is the father's obligation to ensure the family members follow Christ by repenting and being baptised (if not done as baby). The family should understand that repentance means they must turn away from sin, change the direction of their lives, focus on Christ, and depend solely on him for forgiveness of their sins. Furthermore, the family members must be made aware that their baptism identifies them with Christ and with the community of believers. It is a condition of discipleship and a clear sign of faith. As a family, they should act in love towards 
their siblings in Christ, just as God acted in love by sending his Son to die for the sins of all people.

\subsubsection{The Lord's Supper}

The Lord's Supper (also called the "Lord's Table") was instituted on the night when Jesus Christ and his disciples celebrated the Passover (Mt 26:19; Mk 14:16; Lk 22:13). The Lord's Supper was designed to commemorate the death of Christ and the expectation of his return to earth. Within the family circle, it is crucial that children should be included in the Lord's Supper since it is an important practice confirming the Christian faith. The father should perform the Lord's Supper on a regular basis as prescribed in the Bible (1 Cor 11:23; Lk 2:13-20). The significance of this sacrament is that it is a concrete celebration of the family's deliverance from sin through the death and resurrection of Christ. By taking the bread and wine, the family members identify themselves with the death of Jesus Christ and his resurrection. It is also crucial that the father should teach the family that Christ is spiritually present when they consume the signs, and He strengthens them inwardly through his Spirit.

\subsection{The father should underline the importance of children attending church}

The father should make it clear from the outset that it is essential for the children to attend church. Families must attend church as a unit, seeing that these times of worship influence their worldview and life view, which incorporates the family's view of God (De Beer 2012:62-63; Jansen 2015:104). Besides the home, the church is the most appropriate spiritual institution for children to learn about Christian values and the existence of God (Haydon 1997:44). In this regard, the church is the main institution in society that deals with and serves in specific religious aspects such as prayer, spiritual character, faith and confidence (Lickona \& Davidson 2005:193-196).

If children learn Christian values from the church, this institution should be steadfast in its values, principles and norms. Setting the spiritual "benchmark" in society, the church's teaching and fellowship should outweigh the detrimental "themes and schemes" that children receive and adopt from the outside world. Often these children are perceived in a distorted way and treated negatively as a "lost generation" by the outside world. Nevertheless, children should not be seen merely as the church of the future. They are the church of today, seeing that the church's influence can still change their lives, allowing them to make a difference in the world (Freeks 2011a:131).

Furthermore, the church does not only focus on the existence of God, it entails a devotion to spiritual life (Abdool 2005:47). Therefore, it is crucial that the father should teach his children to view the church as the heart of the family's activities, such as praising, worshipping, praying, offering, tithing, testifying, and thanksgiving (Bergh 
2002:160). Whether in church or at home, the father should be a follower of Christ and must portray the fruit of the Spirit (Freeks 2004:97; $c f$. also Gl 5:22-23).

In correlation, the church should not only be considered a place that families frequent to praise and worship God. Families should also view the church as an avenue where they can be educated and taught and where Christian values can be instilled in children. Furthermore, the church should be a dedicated sphere where information is exchanged and shared. Families need to implement this lifestyle of exchanging and sharing information and should exercise the same religious activities at home (Pitout et al. 1990:37).

The church should not always be viewed as the gathering of believers to praise and worship the Lord. The church also has to be a space where children can have fun and enjoy themselves in their relationship with the Lord. It should also be a safe haven where children can be themselves as God intended them to be, without pretence or fear.

\subsection{The Christian and missional role of the father as role model within the home}

People have different perceptions, ideas and suggestions about the family and the context of the father's role. As researcher in the field of fatherhood and families, it is almost too difficult to acknowledge that the traditional family is being eroded continuously (missing the mark ${ }^{3}$ ). Therefore, it is important that the father should understand his fundamental role. This exceeds expectations about status symbols or the father's peers. In the context of this article, the father's Christian and missional role does not entail accumulation of wealth, to be educated first, or have a certain position or work in society and bring home a salary each month. This Christian and missional role of the father focuses on responsibility, accountability, authority, modelling, spending quality time, positive relationships and respect. It entails honouring God for the privilege of being a father, by participating and proclaiming the good work of Christ, either verbally, or by lifestyle and conduct.

It is an obvious fact and natural instinct that a father's ultimate priority is to provide for and to protect his family. However, this role seemingly has changed over the years. This even applies to the traditional roles of mother and father in the family context. Distinctions have been blurred, especially regarding the identity of the breadwinner. Historically, fathers were viewed as the main financial providers for their families, and even referred to as male heads participating on behalf of both women and children.

Regarding children, the father-child relationships at all stages of a child's life has a profound and wide-ranging impact that lasts a lifetime. All men have some

3 The Hebrew words for "sin" (chata; het) means to "miss, go wrong, miss the mark or to fail". The Greek words for sin hamartia (ham-ar-tee-ah) denotes a failure. Missing the mark is a form of guilt or a fault. In the context of this article, the word does not imply committing a felony or misdeed, but rather to be absent, not to be there, and doing something without being present. 
connection to children - as relatives, teachers, coaches, or simply as community members. They may function as biological fathers, stepfathers, adoptive or foster fathers, or legal guardians, brothers, uncles, or grandfathers. Whether they live with their children or not, men's participation has a lasting influence on the lives of children, women, and other men. Furthermore, fathers have an enduring impact on the world around them (Levtov et al. 2015:5-14). This applies even more to the fundamental role of missional fathers within families.

Currently, however, the father role is in crisis due to a social devaluation of the male gender. According to some researchers, this tendency undermines the family, society, and eventually the world, because any nation is only as strong as the family units living in it (Farrar 2003). Since the 1990s, the South African education system, government agencies and the media built have degraded the masculinity of men and have devalued the role of women. Fathers were told that they are in effect becoming redundant in the family context. In contrast to this gendered view, fathers are needed within families since they contribute significantly to the holistic mission of God to reach families.

Furthermore, fathers are important instruments for God since He chooses to work through them to raise righteous children within the family and in society (Farrar 2003). Those who believe, are God's family according to his will (Eph 1:5). However, if the father is absent (emotionally or physically), the children suffer the consequences.

God has given the father authority to lead his family to be faithful to God. The father should exercise this authority lovingly, with a serving and giving attitude - following Jesus Christ as the family's model (Eph 5:23-25; Col 3:19; Pt 3:7). Significantly, this authority relates to the wife as Christ relates to his church. Therefore, the father is commanded to treat his family as Christ treats the church, by giving his life. It is imperative that the father should use this authority to love and to serve his family, even to death (Eph 5:23-25). This is a mandate that involves responsibility rather than a privilege within the family. Responsibility in this context implies spending time with the family, thereby building and maintaining sound relationships.

Furthermore, fathers who spend adequate time with their children tend to be better at caring in the home environment (Freeks 2008:5-9). Commitment to quality time spent with children should make a father more sensitive to their needs and direct his love, attention and discipline (Bingham 2013; Freeman \& Almond 2010:243; Warren 2005:18). Spending time will also allow the father to form a stronger bond with his children. In this way, a father can best discover the children's virtues, fears, aspirations, ideals and hopes (Freeks 2004; Freeks 2011a:173; Steytler 2007:77).

Another valuable aspect in this context is relationships - the golden thread in any family (Steytler 2007:59). The father has to foster a positive relationship with his family, especially his wife. It is essential that the mother should be treated with the necessary respect and consideration. Children who witness affection, respect- 
fulness, and sacrificial behaviour, especially from the father, are more likely later in life to treat their own spouses accordingly (Freeks 2008:22-24; Freeks 2011a:212213; Freeks 2013:12-19; Freeks 2016a:12).

Furthermore, it is crucial that society should understand: families need more good fathers. These fathers and the children they guide and invest in become assets to a society. Therefore, fathers must be sensitised about the different aspects of their role, namely: physical, spiritual, disciplinary and role-model.

\subsection{Physical involvement}

The father's physical involvement stabilises the family and makes it trustworthy to stand firm in the face of challenges. The father and his family can only form a strong bond and be pulled together by the father's physical presence (Freeks 2004; Freeks 2013:12-17).

Regarding the spiritual role, the father has the huge responsibility to portray Jesus Christ on earth and to his family. The father is the one within the family context who must ensure that God is worshipped and obeyed. Therefore, the father's status should be spiritual because people and spirituality combines at the closest level of interaction, which is known as the family (Bergh 2002; Freeks 2013:17-19).

The father should accompany, lead, and direct his family according to Proverbs 1:8-9 (his teachings, their crowning glory). Importantly, he should cultivate a love for God the Father and his Word, thereby encouraging his children to adopt the same lifestyle. He should take the time to teach his family from the Word of God, guiding his children to practice and lead their daily lives according to biblical guidelines. The father can set such an example by being honest, maintaining discipline and showing obedience (Freeks 2016a:9-10). It is important that a father understands his determining role in shaping God's image in the lives of his children (Jordaan \& Janse van Rensburg 2007:33).

The disciplinary role is a principal function that sets limits to behaviour (Freeks 2013:26-27). Effective discipline from the father does not only require wisdom, but also patience and persistence (Euvrard 2006; Rens 2005). Discipline is one of the most important aspects that needs attention when training and educating a child (Mentz \& Wolhuter 2003). Euvrard and Rens mention patience and persistence as effective aspects of discipline. In turn, Mentz and Wolhuter indicate that discipline require training and educating. The researcher concurs, but leans towards the view of Henley (1997) that discipline, teaching and correction is a form of discipling, in other words making disciples or followers with good behaviour and conduct.

Furthermore, the child is directed away from a wrong path onto a right one. In this regard, the father must be an ideal figure who disciplines his children in the fear of the Lord (Freeks 2004; $c f$. Pr 1:9). 
The father also needs to set an example that children can model. A Christian and missional father can be a successful role model for his children if he adheres to the Word of God. It is interesting to know that children look up to people to whom they can relate and whom they can emulate in their development (Barker 2008:1-3).

Thus, children should look up to their parents for providing examples of true conduct. The children should also learn from the father's behaviour and attitude towards life (Freeks 2004). The father's intentions and actions can influence the development of the child's personality significantly (Freeks 2013:26).

In addition, the father can set an excellent example for other fathers by demonstrating how he assists and supports his children. It is also important to grasp the fact that an exemplary role model is not someone who is perfect, but someone who entertains basic values and is able to distinguish right from wrong, good from bad, or valuable from that which is not worth the trouble.

The researcher addressed the vital role of the father in several presentations on local, national, and international forums. The most responses focused on the striking question about the father's un-involvement within the family. The simple answer is that children are tired, frustrated and angry with their fathers for showering them with gifts and money instead of listening to their concerns and suggestions. These children require their father's physical presence; for him to listen to their cries, frustrations, questions and failures. These children's attitude is: "Dad we need your presence more than your presents!"

When fathers engage in family matters, it results in meaningful connections, happiness and positive attitudes among the children. Therefore, the father's physical involvement could help children thrive in life due to improved cognitive development and achievement at school (Levtov et al. 2015:5-14). The father's involvement with his children may require sacrificial time, for example enjoying meals together and helping out with the homework. Furthermore, the father must be aware of what his children are reading, watching, and hearing. He should know the name of his child's teacher, the child's favourite television show(s) or radio station(s), the friends, movie star(s), or sports celebrities (Farrar 2003).

\subsection{The father and his family should be involved in the needs of its community}

Primarily, every Christian family should be committed to mission and the needs of the community. The reason is that mission forms part of the larger role the church plays in the story of God; also by establishing spiritual unity (Goheen 2011:218-219).

Spiritual unity is essential in the context of the present study. If the church finds it hard to survive without spiritual unity, this applies even more to the family. Families should live in unity with God the Father and should understand the will and purpose of the Triune God. Jesus prayed according to John 17:21 that his followers 
should all be one as the Father is in Him, and He is in the Father so that the world can believe that the Father sent Him (Eph 1:10; $c f$. also Stringer 2009:102; Goheen 2011:225).

Based on the above-mentioned spiritual unity, it is important that families should be united in their community involvement. They should give to others and share with them, thereby helping eliminate poverty in their community. If families are not united, they are in disunity, which contradicts what the Gospel teaches (Goheen 2011:225). Therefore, families who are cared for, should not allow their fellow humans to suffer. The family should share and give voluntarily. It is important for families to adopt an attitude that testifies: Everything they have or did receive in life are from God. This also applies to the possessions they have: They are stewards of God's riches. This should be the mind-set of a united family (Goheen 2011:217; $c f$. also Ac 4:32-35).

Families who cater for the needs of the community must first of all be a missional family, concerned to demonstrate the unity of the church in practice. Furthermore, the family members should commit themselves to seek and to express the oneness they share in Christ (Goheen 2011:226).

The father should make his family aware of the fact that evangelistic activity in a community is driven by the life-transforming power of the Spirit through the Word of God. Therefore, the father should teach the family that words must be authenticated by deeds of mercy and justice. Such deeds are expressions of self-giving love and can be a powerful testimony to the truth of the Gospel (Goheen 2011:218).

Despite family difficulties in the home, the members should give themselves as a token of love and a witness to the truth of the Gospel. Communities have numerous needs, and churches are not always sensitive to the basic needs of the people in a community. Therefore, the family, with the father as leading figure, should be a welcome presence in society, giving and providing to people in their needs. The family as unit should take responsibility for the needs of their community (Goheen 2011:17).

Furthermore, families should be pacesetters in their missionary encounter with communities. Such an encounter, in the context of the present study, means that a family does not live for itself, but it is involved in the matters and concerns of its community, which is part of the missionary task (Goheen 2011:217 \& 220), namely to establish a witness in society. For that reason, the family with the father as leading figure, can be the ideal witness of good news in its community. Missionary families should testify to other families in the community about God's grace, mercy and love (Goheen 2011:217-220).

Regarding children and faith, the father should be trained to take on the task and responsibility of nurturing his and other children about their faith. Families transfer 
the faith to the next generation. The future of the church as a missional community will be bleak if families are not taught, trained and equipped to make commitments to nurture theirs and other children. They are the future of society (Goheen 2011:221). As Goheen aptly puts it: "What will it profit families if they gain the whole world, but lose their children?" (Goheen 2011:223; $c f$. also Mk 8:36-37).

The researcher believes that Christian and missional fatherhood should have a strong trinitarian vision that should be emphasised in Christian families. The aim will be to teach, train and equip families about a trinitarian vision for their important missional task within their community.

\subsection{The ministry of churches in communities with broken families and father-} less children

God reveals himself as a Father of the fatherless and protector of widows from his "holy habitation, who settles the solitary in a home" (Ps 68:5 cf. also Is 10:1-2; Am 2:6-7). From the New Testament testimony, the Lord's purpose is made clear. He wants to accomplish these actions through the ministry of the church. This is true religion before God the Father through loving care for orphans and widows in their affliction (Ja 1:27). The church, as the body of Christ on earth, are the Lord's hands and feet and compassionate heart. Therefore, the church should equip its members (and especially Christian families) to minister to these children at risk and to bring them the hope of transformed lives (Center for Mission Mobilization 2010).

\section{Possible and practical solutions}

In light of the above, it is necessary to train and equip fathers and mothers and young married couples. This should take place through various strategies: workshops, road shows, seminars, conferences, camps on marriage and family enrichment, premarital counselling programmes, equipping events, as well as programmes and activities for community training. All these strategies should focus on building strong and steadfast families and training effective parents.

The church should urgently reach out to these families with assistance programmes. In this way, the local church becomes God's instrument, bringing salvation and hope to people in poor communities (Lipscomb 2015). Thus, the church demonstrates the love of God the Father through His Son, Jesus Christ, to help the disadvantaged and less fortunate. The aim should be to transform the lives of these mentioned groups with dignity, hope and respect. The focus of such programmes should be those orphaned by HIV/Aids, fatherless children, child-headed households, sexually abused young girls, and vulnerable, abandoned children (Lipscomb 2015).

If the church fails to fulfil this mandate, it not only fails the children, but also grieves God the Father. 
In communities where fathers are absent and there is a lack of father figures, camps should be organised. At these camps, young leaders should be identified and new fathers and mothers sensitised through relevant training courses. Furthermore, it is essential that the youth should be trained through fatherhood programmes. Growing boys and young men must be equipped through Bible studies and biblical courses to grasp and realise the notion of missional fatherhood.

The teaching should also focus on younger children, including those without fathers, orphans, also those orphaned by the Aids epidemic, child-headed households and vulnerable children. Christian education will guide children to become part of the body of Christ (Goheen 2011:223). Christian education based on the Word of God can shape the various aspects of people's lives (Goheen 2011:222).

Children and youth should be equipped with life skills based on Christian values for a positive change to influence the community as a whole. Examples of Christian values are obedience, prayer, sanctification, worshipping, assurance in faith, deliverance, purity, patience and humility (Freeks 2011a:214). A further goal is that families should re-accept their God-given responsibility to nurture their children according to the guidance of God's Word.

\section{Recommendations}

A Christian and missional father shows specific characteristics, and here are some of the basic traits:

Mission is selfless: The father should explain to his family that making disciples should be a selfless undertaking. Furthermore, children must understand that Christ gave himself to others. Fathers should follow this example by living a life focused on others to the glory of the heavenly Father. In this way, fathers teach their children to live and have a heart for mission.

Learn to be broken for others: This means giving, praying, and investing more in the lives of other people. It is crucial that children see the father giving to those who are in need and helping out others. A missional father should apply 1 Thessalonians 2:8 in his life as a father: emphasising love for others and giving oneself to others.

Live Christ-focused: It is imperative that children should to see their father being overwhelmed by Jesus in his life. The focus and motivation of the father should be on Jesus Christ, and his children should see him serving the Lord.

Be Spirit-led: A father should follow the guidance of the Holy Spirit in all his ways, with his decisions, advice and lifestyle. He should share with his children the testimony of how the Holy Spirit answered their prayers as a family.

Be generous: He should constantly bless other people with the blessing with which Christ has blessed him. This father's time, money and energy should be used 
to help other people. The researcher suggests that the father encourages his children to adopt an attitude of giving their money, gifts and energy to the church and community.

Live for God and others: Christian and missional fathers should live for God and other people. They should know that their lives are not their own, but a blessing from God. Such fathers should thus be Christians and missionally-minded and disciplemakers in their homes and their respective communities ( $c f$. Cousineau 2013).

\section{Conclusion}

Society and communities are in desperate need of religious and committed fathers for their families. Such a father sets an example by following God as heavenly Father. Fathers are tasked in their Christian and missional calling to reflect the image of God. In this way, they demonstrate the true meaning of a loving (triune) relationship with God as heavenly Father through his Son Jesus Christ in the power of the Spirit. A loving father mirrors the goodness, mercy and love of God in a unique way within the various life contexts: his family, in church, at work, among friends, and in his community. Christian fathers also have the opportunity to be used by God to influence their family. It is essential for Christian and missional parenthood that fathers receive Jesus Christ as their Saviour and become children of God. No father can be saved and not intentionally seek to build Christ's love and presence into the lives of his family. Therefore, fathers should know that fatherhood is a God-given calling. They have to be models that embody the quantities and missional purpose of Christ's new commandment. In practical life, this implies loving others as Christ loves them. If fathers succeed in this area, they have fulfilled their calling in life where it matters the most, namely family life.

\section{References}

Abdool, A.D. 2005. Die waarde-oriëntering van leerders in sekondêre skole.

Potchefstroom: Noordwes-Universiteit. (Proefskrif - PhD).

Amoateng, A.Y., Richter, L.M., Makiwane, M. \& Rama, S. 2004. Describing the structure and needs of families in South Africa: towards the development of a national policy framework of families. A report commissioned by the Department of Social Development. Pretoria: Child Youth and Family Development, HSRC. https:/www.google.com/ url?sa $=\mathrm{t} \& \mathrm{rct}=\mathrm{j} \& \mathrm{q}=$ \&esrc $=\mathrm{s} \&$ source $=$ web\&cd =2\&ved $=0$ ahUKEwj6z6ahzYTQAhVD GsAKHdE8CEcQFgglMAE\&url=http\%3A\%2F\%2Fwww.hsrc.ac.za\%2Fen\%2Fresearchoutputs\%2Fktree-doc\%2F1224\&usg=AFQjCNGJDEtbNLzHYydKnfGHkZyK8WcYIQ\&sig2 $=x E A R 08$ re8JOcDVaa1lTtFg\&cad $=$ rja Date of access: 11 Jul. 2018.

Anon. 2004. Lessening the impact of fatherlessness. Natal Witness. 16, 24 Jun. 
Anon. 2008a. The fatherless sons of violence. Cape Argus: 15, 23 Jun.

Anon. 2008b. The fatherless sons of violence. Star: 35, 25 Jun.

Anon. 2016a. 4 Biblical models for successful parenting.

http://www.missionalwomen.com/family/4-biblical-models-for-successful-parenting. Date of access: 11 Jul. 2018.

Barker, C.J. 2008. James Bernard: fatherhood means leadership and commitment. New York Amsterdam news, 99(25):5.

Bartlett, E. 2013. Die impak van afwesige vaders op adolessente meisies se psigososiale welstand. Potchefstroom: Noordwes-Universiteit. (Skripsie - Honns BA).

Bergh, S.J. 2002. Gesinsbediening as 'n geïntegreerde deel van die opbou van die gemeente. Bloemfontein: Universiteit van die Oranje Vrystaat. (Proefskrif - DTh).

Bertelsmann, M. 2016. Where have our fathers gone? http://www.parent24.com/Family/ Parenting/where-have-our-fathers-gone-20160217-2 Date of access: 11 Jul. 2018.

Bevins, W. 2016. Becoming a missional family. Seedbed, 4 Sept. http://www.seedbed.com/ becoming-a-missional-family-2/ Date of access: 11 Jul. 2018.

Bible. 1965. The amplified Bible. Grand Rapids, MI: Zondervan.

Bible. 1983. (NIV) Thompson chain reference Bible. Grand Rapids, MI: Zondervan.

Bible. 1984. The Holy Bible: new international version. Grand Rapids, MI: Zondervan.

Bible. 2001. The soul care Bible. New King James Version. Nashville, TN: Thomas

Nelson. Bingham, N.W. 2013. Fathers need to stop stealing from their kids. http://www. churchleaders.com/youth/youth-leaders-articles/170991-nathan-bingham-stop-stealing-from-their-kids.html?utmsource=newsletter\&utmmedium=email \&utmcampaign =clnewsletter\&utmcontent=CL+Daily+20131109 Date of access: 11 Jul. 2018.

Brelsford, G.M. 2011. Divine alliances to handle family conflict: theistic mediation and triangulation in father-child relationships. Psychology of religion and spirituality, 3(4):285-297.

Brooks, J. 2008. The process of parenting. 7th ed. Boston, MA: McGraw-Hill.

Buys, F. 1983. Ons huis 'n poort na Christus en sy gemeente. (In Venster op die gesin: openhartige gesprekke met ouers, kinders en familie. Potchefstroom: PU vir CHO. p. 320-328). (Wetenskaplike bydraes van die PU vir CHO. Instituut vir Reformatoriese studies, Reeks F3: Versamelwerke no. 19).

Carstens, C. 2014. The world needs a father: a trainers' guide. Cape Town: Paarl Media Printers.

Center for Mission Mobilization. Stand4Kids. 2010. Children at risk. Stand4Kids. http:// www.stand4kids.org/28-2/ Date of access: 11 Jul. 2018.

Cousineau, J. 2013. Five characteristics of a missional father. http://cbmw.org/topics/ fatherhood/5-characteristics-of-a-missional-father Date of access: 11 Jul. 2018.

De Beer, C. 2012. The characteristics of a missional church as part of the missio Dei. Potchefstroom: North-West University. (Dissertation - MTh).

Dobbs, P. 2013. The impact of fatherlessness on the way one relates to God as Father. Dunedin: University of Otago. (Dissertation - MTh). http://hdl.handle.net/10523/4672

Dube, D. 2016. 2.13 million kids in SA fatherless. The New Age: 2, 5 Jul. http://www.ann7. com/2-13-million-kids-in-sa-fatherless/ Date of access: 11 Jul. 2018. 
Euvrard, G. 2006. The Values Manifesto project. Educational leadership, 63(8):1-6.Family Life. 1998. A declaration of timeless values.

http://www.familylife.org.za//?s=declaration+of+timeless+values Date of access: 11 Jul. 2018.

Farrar, S. 2003. Seven steps for effective fathering. Lifeway, 2 June. http://www.lifeway. com/Article/Seven-steps-for-effective-fathering Date of access: 11 Jul. 2018.

Feni, L. 2016. Forum raises concern over fatherless society. Daily Dispatch: 2, 21 Mar.

Ford, J., Nalbone, D.P., Wetcher, J.L. \& Sutton, P.M. 2008. Fatherhood: how differentiation and identity status affect attachment to children. American journal of family therapy, 36(4):284-299.

Frazier, T. 2015. The result of fatherlessness in South Africa. http://www.tumifrazier.com/ fatherlessness-in-south-africa/ Date of access: 11 Jul. 2018.

Freeks, F.E. 2004. Die rol van die ontbrekende vaderfiguur in die Suid-Afrikaanse konteks. 'n prakties-teologiese studie. Potchefstroom: Noordwes Universiteit. (Verhandeling MA).

Freeks, F.E. 2008. Manual for course facilitators: LIFEPLAN®. Potchefstroom: North-West University. AUTHeR (Africa Unit for Transdisciplinary Health Research).

Freeks, F.E. 2011a. The role of the father as mentor in the transmission of values: a pastoral-theological study. Potchefstroom: North-West University. (Thesis - PhD).

Freeks, F.E. 2013. Dad is destiny: the man God created to be. Potchefstroom: Ivyline Technologies.

Freeks, F.E. 2016a. Die noodsaak van Skrifgefundeerde vaderskap as antwoord op die voortslepende probleem van vaderskapafwesigheid in Suid-Afrika. Tydskrifvir Christelike wetenskap, 52(1\&2):1-27.

Freeks, F.E. 2018. A Missional evaluation of the LIFEPLAN® Training and Equipping Programme for youth in rural areas. A case study of its impact in the Christiana district in South Africa. Potchefstroom: North-West University. (Thesis-PhD).

Freeks, F.E., Greeff, M. \& Lotter, G.A. 2015. Views of Christian fathers of their role as mentors in the transmission of values within the family. Journal for Christian scholarship, 51(1):21-45.

Freeks, F.E. \& Lotter, G.A. 2009. 'n Prakties-teologiese ondersoek na die uitwerking van afwesige vaders: 'n verkennende kwalitatiewe ondersoek in die Promosa-gemeenskap. Koers, 74(3):519-534.

Freeman, H. \& Almond, T.M. 2010. Mapping young adults' use of fathers for attachment support: implications on romantic relationship experiences. Early child development and care, $180(1 \& 2): 227-248$.

Goheen, M.W. 2011. A light to the nations: the missional church and the biblical story. Grand Rapids, MI: Baker Academic.

Goodsell, T.L. \& Meldrum, J.T. 2010. Nurturing fathers: a qualitative examination of childfather attachment. Early child development and care, 180(1-2):249-262.

Hans, B. 2008. Local children left fatherless. Witness: 5, 28 May. http://www. news 24.com/archives/witness/local-children-left-fatherless-20150430 Date of access: 11 Jul. 2018. 
Hart, A. \& Hart Frejd, S. 2010. Modern stress, technology and parenting. Christian counselling today, 18(2):16-19.

Hawkins, C. 2015. Most SA households run by single moms. SA breaking news, 3 Sept. http://www.sabreakingnews.co.za/2015/09/03/most-sa-households-run-by-singlemoms/ Date of access: 11 Jul. 2018.

Haydon, G. 1997. Teaching about values: a new approach. London: Cassell.

Henley, K. 1997. Child-sensitive teaching: helping children grow a living faith in a loving God. Nashville, TN: Zondervan.

Herald Reporter. 2002. EC-Mayor concerned over fatherless kids. The Herald: 8, 18 Apr.

Jansen, A. 2015. 'n Holistiese perspektief op die missio Dei: 'n evaluering van die sendingwerk van die Christelijke Gereformeerde Kerken in KwaNdebele (RSA). Potchefstroom: Noordwes-Universiteit. (Proefskrif - PhD).

John, V. 2012. Fatherless children find their voices. Mail \& Guardian: 24, 21Jun.

Jordaan, A. \& Janse van Rensburg, J. 2007. Die rol van die vader by veralgemeende angsversteuring. In die Skriflig, 41(1):23-44.

Knafo, A. 2003. Authoritarians, the next generation: values and bullying among adolescent children of authoritarian fathers. Analyses of social issues and public policy, 3(1):199-204.

Levtov, R., Van der Gaag, N., Greene, M., Kaufman, M. \& Barker, G. 2015. State of the world's fathers: executive summary: a mencare advocacy publication. Washington, DC: Promundo, Rutgers, save the children, Sonke gender justice, and the Menengage Alliance.

Lickona, T. \& Davidson, M. 2005. Smart and high schools: integrating excellence and ethics for success in school, work and beyond: a report to the nation. https://www2.cortland. edu/centers/character/high-schools/SnGReport.pdf Date of access: 11 Jul. 2018.

Linn, J.G., Wilson, D.R. \& Fako, T.T. 2015. Historical role of the father: implications for childbirth education. International journal of childbirth education, 30(1):12-18.

Lipscomb, P.J. 2015. Local church assistance programs. http://freefinancialhelp.net/ church-assistance-programs/ Date of access: 11 Jul. 2018.

Magruder, J. 2014. Missional family, missional kids. http://www.lifeway.com/kidsministry/2014/10/14/missional-family-missional-kids Date of access: 11 Jul. 2018.

McGraw, P. 2004. Family first: your step-by-step plan for creating a phenomenal family. New York, NY: Free Press.

Meintjies, H. \& Hall, K. 2013. Demography of South Africa's children. (In Berry, L.,

Biersteker, L., Dawes, A., Lake, L. \& Smith, S., eds. South African child gauge. Cape Town: University of Cape Town, Children's Institute. p. 86-89). http://www.ci.org.za/depts/ci/pubs/ pdf/general/gauge2013/SouthAfricanChildGauge2013.pdf Date of access: 11 Jul. 2018.

Mentz, P.J. \& Wolhuter, C.C. 2003. 'n Perspektief op die voorkoms van dissiplinêre probleme in Afrikaanse skole. Koers, 68(4):391-412.

Mkhize, V. 2013. Black young, poor and fatherless. Star: 2, 19 Nov.

Morris, R. 2007. The single parent's handbook. Harlow: Pearson Education.

Pitout, D.N., Smith, A.G., Windell, J.H.J. \& Steinmann, A.R. 1990. Teachers' handbook for education. Pretoria: Van Schaik. 
Popenoe, D. 1996. A world without fathers. Wilson quarterly, 20(2), 12-16.

Ratele, K., Shefer, T. \& Clowes, L. 2012. Talking South African fathers: a critical examination of men's contributions and experiences of fatherhood and fatherlessness. South African journal of psychology, 42(4):553-563.

Rens, J.A. 2005. Riglyne vir waarde-opvoeding in Suid-Afrikaanse skole. Potchefstroom: Noordwes-Universiteit. (Proefskrif-PhD).

Richter, L., Chikovore, J. \& Makusha, T. 2010. The status of fatherhood and fathering in South Africa. Childhood education, 86(6):360-365.

Richter, L., Desmond, C., Hosegood, V., Madhavan, S., Makiwane, M., Makusha, T., Morrel, R. \& Swartz, S. 2012. Fathers and other men in the lives of children and families. Paper presented at Strategies to Overcome Poverty and Inequality, the "Towards Carnegie III" Conference at the University of Cape Town. 3-7 Sept. http://carnegie3.org.za/docs/ papers/231_Richter_Fathers\%20and\%20other\%20men\%20in\%20the\%20lives\%20 of $\% 20$ children\%20and\%20families.pdf Date of access: 11 Jul. 2018.

Smail, T.A. 1980. The forgotten Father: rediscovering the heart of the Christian Gospel. Sydney: SCM Press.

Staples, R. 1999. The Black family. Belmont, CA.: Wadsworth. StatsSA. 2015a. General household survey, 2014. Statistical release P0318.

Pretoria. http://www.washingtongroup-disability.com/wp-content/uploads/2016/03/2014_ GHS_report.pdf Date of access: 28 Nov. 2016.

Steytler, J.P.D. 2007. Mentorskap in die maatskaplike funksionering van die seun in sy laat-middelkinderjare. Potchefstroom: Noordwes-Universiteit. (Verhandeling - MA).

Stringer, D. 2009. Hope for a fatherless generation: rebuilding our foundations. Shippenensburg: Destiny Image.

Swartz, S., Bhana, A., Richter, L. \& Versfeld, A. 2013. Promoting young fathers' positive involvement in their children's lives. Pretoria: HSRC. http://www.hsrc.ac.za/en/research-data/ktree-doc/11605 Date of access: 11 Jul. 2018.

Vaughan, J. 2010. Dads and the daughters they love. http://www.focusonthefamily.ca/parenting/fatherhood/dads-and-the-daughters-they-love Date of access: 11 Jul. 2018.

Waresak, J.T. 2016a. 5 keys to lead your wife, i.e. 'wear the pants'. http://www.drjamesdobson.org/blogs/the-fatherhood-challenge/the-fatherhood-challenge/2016/06/22/5keys-to-lead-your-wife-ie-wear-the-pants Date of access: 11 Jul. 2018.

Waresak, J.T. 2016b. Missional fatherhood. http://www.drjamesdobson.org/blogs/thefatherhood-challenge/the-fatherhood-challenge/2013/11/11/missional-fatherhood Date of access: 11 Jul. 2018.

Warren, R.C. 2005. Our fathers who are on earth: if Satan thinks they are a key battleground, shouldn't we? Christianity today, 49(5):53.

Wax, T. 2016. Jesus-centered parenting in a child-centered world. https://blogs.thegospelcoalition.org/trevinwax/2014/07/10/jesus-cetered-parenting-in-a-child-centeredworld Date of access: 11 Jul. 2018.

Williams, A. 2008. We badly need good fathers. Human events, 64(21):18.

Williams, R.B. 2014. The male identity crisis and the decline of fatherhood. Psychology today. http://www.psychologytoday.com/em/152400 Date of access: 11 Jul. 2018. 